\title{
Corrosion of Aluminum Irradiated in Atomic Reactor
}

\author{
Masayuki KAwASAKI*, Sueo NomURA* and Noboru ITO*
}

For preliminary test of radiation corrosion of aluminum in atomic reactor, we measured the induced activities of aluminum specimens, and compared the corrosion resistance of these pile-irradiated specimens in high purity water at elevated temperatures with those of uniradiated ones.

The experiment was performed with three kinds of Al specimens containng 99.0, 99.9 and 99.99 weight percent $\mathrm{Al}$ respectively, and they were intermittently exposed in the thermal neutron flux of $2 \times 10^{11} \mathrm{n} / \mathrm{cm}^{2} \mathrm{sec}$. for one or two weeks until the total amount of thermal neutron became 2 or $4 \times 10^{16}$ $\mathrm{n} / \mathrm{cm}^{2}$.

After removal from pile, the induced activities of these specimens were measured everyday by G-M counter (Fig. 1), and sometimes by a Gamma-ray spectrometer (Fig. 2). We unexpectedly found that pure aluminum specimens of 99.9 and $99.99 \%$ had higher residual activities than the otherone, and it was caused mainly by $\mathrm{Sb}^{*}$ which also proved its exsistence by Kraus' ion exchange method ${ }^{(1)}$ later.

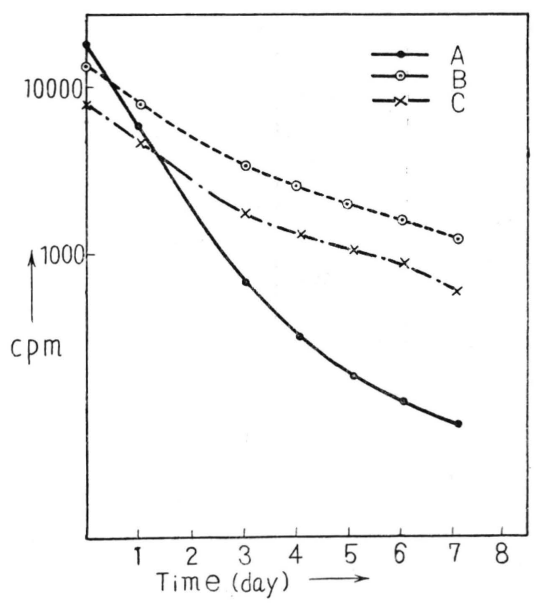

Fig. 1 Decay curves of impurities in pile-irradiated Al samples.

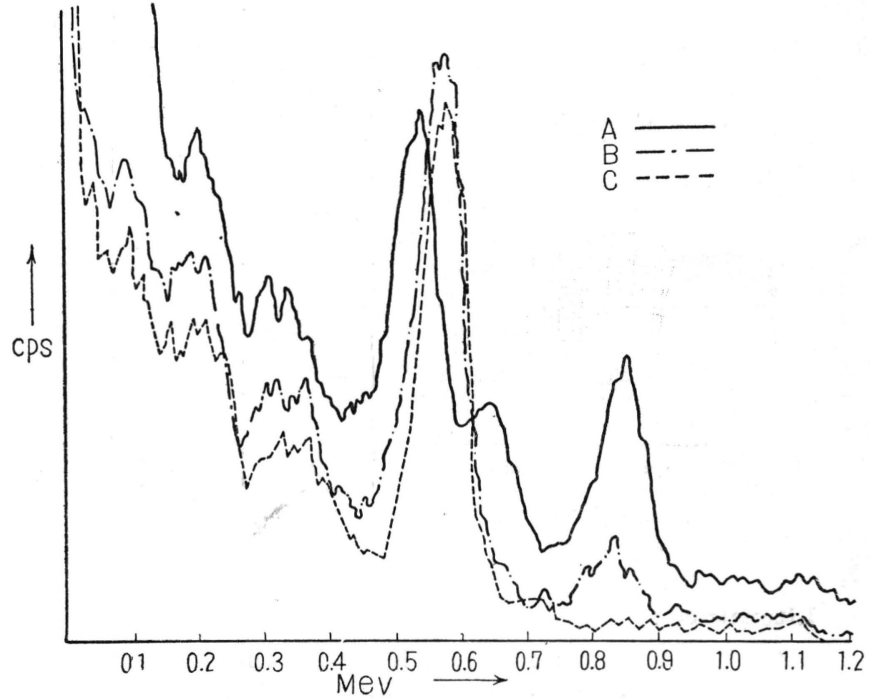

Fig. 2 r-ray spectrogram of irradiated Samples after 2 days from removal.

The difference of corrosion behavior between irradiated and unirradiated specimens was observed in high purity water which had above $400 \mathrm{kilo}-\mathrm{ohm}$ specific resistance, at 80,100 and $200^{\circ} \mathrm{C}$. for 25,20 and 9 hours respectively.

The results of the corrosion test are shown in Table. 1, 2 and 3 in which the degree of corrosion is indicated by weight gain per initial weight of sample because all specimens have the same thickness of $1 \mathrm{~mm}$. and therefore the initial weight of sample corresponds to its surface area.

From these results, we can see the effect of irradiation on corrosion is negligible or very little. We also studied the corrosion properties of irradiated and unirradiated specimens with and without surface treatment of abrasion by emery paper.

* Tokai Laboratory, Japan Atomic Energy Research Institute, Tokaimura, Ibaraki-ken.

The original written in Japanese can be seen in J. Electrochem. Soc. Japan, 26, 624 (1958). 
Table 1 Corrosion of Aluminum at $80^{\circ} \mathrm{C}, 25 \mathrm{hrs}$.

\begin{tabular}{c|c|c|c|c}
\hline \hline Sample & $\mathrm{A}$ & $\mathrm{B}$ & $\mathrm{A}$ & $\mathrm{B}$ \\
\hline Condition of irradiation & $455.5 \mathrm{kWh}\left(\mathrm{ca} 2 \times 10^{16} \mathrm{n} / \mathrm{cm}^{2}\right)$ & 1.78 & 1.16 & 1.95 \\
\hline Weight gain $(\mathrm{mg} / \mathrm{g})$ & 1.29 & 7.75 & 7.45 & 7.5 \\
\hline $\mathrm{pH}$ & 7.55 & 98.00 & 105.00 & 100.00 \\
\hline Specific resistance $(\mathrm{k} \Omega)$ & 71.00 & & 1.00 \\
\hline
\end{tabular}

Original water: $\mathrm{pH} 6.0$ specific resistance $420 \mathrm{k} \Omega$.

Table 2 Corrosion of Aluminum at $100^{\circ} \mathrm{C}, 20 \mathrm{hrs}$.

\begin{tabular}{c|c|c|c|c|c|c}
\hline \hline Sample & A & B & C & A & B & C \\
\hline Condition of irradiation & $425.6 \mathrm{kWh}\left(\mathrm{c} \mathrm{a}_{2} \times 10^{16} \mathrm{n} / \mathrm{cm}^{2}\right)$ & & \\
\hline Weight gain $(\mathrm{mg} / \mathrm{g})$ & 1.34 & 1.90 & 3.58 & 1.68 & 2.06 & 5.26 \\
\hline $\mathrm{pH}$ & 7.88 & 8.05 & 7.85 & 7.15 & 7.68 & 7.60 \\
\hline Specific resistance $(\mathrm{k} \Omega)$ & 34.00 & 36.00 & 37.00 & 37.00 & 37.00 & 39.00 \\
\hline
\end{tabular}

Original water: $\mathrm{pH} 6.5$ Specific resistance $500 \mathrm{k} \Omega$.

Table 3 Corrosion of Aluminum at $200^{\circ} \mathrm{C}, 9 \mathrm{hrs}$.

\begin{tabular}{|c|c|c|c|c|c|c|}
\hline Sample & A & B & $\mathrm{C}$ & A & B & $\mathrm{C}$ \\
\hline Condition of irradiation & \multicolumn{3}{|c|}{$455.5 \mathrm{kWh}\left(\mathrm{ca}_{2} \times 10^{16} \mathrm{n} / \mathrm{cm}^{2}\right)$} & \multicolumn{3}{|c|}{-} \\
\hline Weight gain $(\mathrm{mg} / \mathrm{g})$ & 3.81 & 6.99 & 185.5 & 3.10 & 6.92 & 180.4 \\
\hline $\mathrm{pH}$ & 7.33 & 7.38 & 7.80 & 7.16 & 7.30 & 7.33 \\
\hline Specific resistance $(\mathrm{k} \Omega)$ & 29.5 & 30.0 & 36.0 & 29.0 & 30.0 & 34.0 \\
\hline Sample & A & B & $\mathrm{C}$ & A & B & $\mathrm{C}$ \\
\hline Condition of irradiation & \multicolumn{3}{|c|}{$927.4 \mathrm{kWh}\left(\mathrm{ca}_{4} \times 10^{16} \mathrm{n} / \mathrm{cm}^{2}\right)$} & \multicolumn{3}{|c|}{-} \\
\hline Weight gain $(\mathrm{mg} / \mathrm{g})$ & 2.50 & 7.00 & 178.1 & 2.34 & 7.77 & 176.2 \\
\hline $\mathrm{pH}$ & 7.00 & 7.25 & 7.45 & 6.95 & 7.15 & 7.65 \\
\hline Specific resistance $(\mathrm{k} \Omega)$ & 27.0 & 27.0 & 33.0 & 25.0 & 30.0 & 31.0 \\
\hline
\end{tabular}

Original water: $\mathrm{pH} 7.0$ Specific resistance $450 \mathrm{k} \Omega$.

(Received August 22, 1958)

\section{Literature :}

(1) K.A. Kraus and F. Nelson: International Conference on the Peaceful Use of Atomic Energy VII p. 113 (1955) 